\title{
Penggunaan Flashcard Game dalam Penerapan Cognitive Behaviour Therapy (CBT) Pada Pasien Skizofrenia dengan Masalah Harga Diri Rendah
}

\section{The Use of Flashcard Games in the Application of Cognitive Behavior Therapy (CBT) in Schizophrenic Patients with Low Self-Esteem Problems}

\author{
Sri Maryatun ${ }^{1}$, Zulian Effendi ${ }^{2}$, Sayang Ajeng Mardhiyah ${ }^{3}$ \\ ${ }^{1,2}$ Program Studi Ilmu Keperawatan, Universitas Sriwijaya Palembang, Indonesia \\ ${ }^{3}$ Program Studi Ilmu Psikologi, Universitas Sriwijaya Palembang, Indonesia
}

\section{ARTICLE INFO}

\section{Article history}

Received date

17 Feb 2021

Revised date

25 Feb 2021

$09 \mathrm{Jul} 2021$

Accepted date

03 Aug 2021

Keywords:

Cognitive Behavior

Therapy (CBT);

Flashcard;

Low esteem therapy.

\section{Kata kunci:}

Cognitive Behavior

Therapy (CBT);

Flashcard;

Harga diri rendah.

\author{
ABSTRACT/ ABSTRAK
}

Low self-esteem is one of the negative symptoms experienced by schizophrenia patients. A person evaluates himself as low, not good, always fails, is useless to become a burden and stressor for others in an extended period without any support or support system from the environment, raises the risk of suicide. This situation is a serious concern for all parties, especially health workers to be able to provide comprehensive and effective mental nursing care management, namely Cognitive Behaviour Therapy(CBT). This study was aimed to determine the effectiveness of CBT with flashcards on changes in signs and symptoms of low self-esteem in schizophrenic patients. Group therapy based on Cognitive Behavior Therapy (CBT) with flashcard media is one of the development and innovation models of psychotherapy that has an impact on increasing self-esteem in schizophrenia patients because the flashcard method makes it easier for patients to find positive thoughts in the form of communicative and interactive games so that patients feel their self-esteem increases and can behave adaptively. The research design was used a quasi-experimental pre-posttest with a control group. A sample of 50 people includes 25 people in the intervention group and 25 people in the control group. The results were showed that the reduction in signs and symptoms of low self-esteem in schizophrenic patients was greater in the intervention group than in the control group ( $\mathrm{p}$-value $\leq 0,05$ ). CBT therapy with flashcards was effective in reducing low self-esteem by $65,6 \%$. CBT therapy with flashcards is recommended as an effective, efficient, and easy therapy for health workers and families to increase self-esteem for clients.

Harga diri rendah merupakan salah satu gejala negatif yang dialami oleh pasien skizofrenia. Seseorang menilai dirinya rendah, tidak baik, selalu gagal, tidak berguna menjadi beban dan stressor bagi orang lainnya dalam jangka waktu memanjang tanpa adanya dukungan atau support system dari lingkungangan memunculkan resiko bunuh diri. Keadaan tersebut menjadi perhatian yang serius bagi semua pihak khususnya tenaga kesehatan agar mampu memberikan penatalaksanaan asuhan keperawatan jiwa yang komprehensif dan efektif yaitu dengan Cognitive Behaviour Therapy (CBT). Penelitian ini bertujuan untuk mengetahui efektivitas CBT dengan flashcard terhadap perubahan tanda dan gejala harga diri rendah pada pasien schizoprenia. Terapi kelompok berbasis Cognitive Behaviour Therapy (CBT) dengan media Flashcard merupakan salah satu model pengembangan dan inovasi dari psikoterapi yang berdampak pada peningkatan harga diri pasien skizofrenia dikarenakan metode Flashcard memudahkan pasien menemukan pikiran positif dalam bentuk permainan yang komunikatif, interaktif sehingga pasien merasa harga dirinya meningkat dan mampu berperilaku adaptif. Desain penelitian quasi experimental pre-post-test with control group. Sampel berjumlah 50 orang meliputi 25 orang kelompok intervensi dan 25 orang kelompok kontrol. Hasil penelitian menunjukkan penurunan tanda gejala harga diri rendah pasien skizofrenia lebih besar pada kelompok intervensi dibandingkan kelompok kontrol ( $p$-value $\leq 0,05)$.Terapi CBT dengan flashcard efektif menurunkan perilaku harga diri rendah 65,6\%. Terapi CBT dengan flashcard direkomendasikan sebagai terapi efektif, efisien dan mudah dilakukan oleh tenaga kesehatan serta keluarga untuk meningkatkan harga diri klien.

Corresponding Author:

Sri Maryatun

Program Studi Ilmu Keperawatan, Universitas Sriwijaya Palembang, Indonesia

Email: tunce79@yahoo.com 


\section{PENDAHULUAN}

Prevalansi angka gangguan jiwa mengenai lebih dari 450 juta orang setiap tahunnya (WHO, 2011). Gangguan jiwa ditemukan disemua negara, terjadi pada semua tahap kehidupan, termasuk orang dewasa dan cenderung terjadi peningkatan gangguan jiwa. Berdasarkan data Riskesdas 2013 menunjukkan prevalensi gangguan jiwa mencapai $5,6 \%$ dari jumlah penduduk atau 1,7 permil. Angka tersebut meningkat menjadi $14,5 \%$ atau 8 permil rumah tangga artinya per 1.000 rumah tangga terdapat 8 rumah tangga Orang Dengan Gangguan Jiwa (ODGJ) (Syamsulhadi, 2018). Menurut data dari medical record di Rumah Sakit Ernaldi Bahar Provinsi Sumatera Selatan, jumlah pasien perilaku kekerasan pada tahun 2017 berjumlah 3.200 orang, pada tahun 2018 mengalami peningkatan berjumlah 4534 orang yang dirawat di Rumah Sakit Ernaldi Bahar Provinsi Sumatera Selatan dengan angka kekambuhan penyakit 13\% (Laporan PKL, 2017)

Menurut Alliance on Mental Ilness of America, gangguan jiwa merupakan kondisi kesehatan individu yang ditandai dengan terjadinya gangguan pada pola pikir, perasaan mood, ketidakmampuan dalam berinteraksi dan melakukan aktifitas sehari-hari (Stolzer, 2016). Data statistik dari Kemenkes tahun 2018 menunjukkan klien gangguan jiwa berat terbesar adalah skizofrenia $70 \%$ dan klien yang dirawat di rumah sakit jiwa di seluruh Indonesia 90\% dengan skizofrenia (Kementerian Kesehatan RI, 2018). Skizofrenia dapat disebabkan karena sebelumnya klien mengalami stressor menegangkan yang mengancam ego yang sudah lemah, sering berpikir negatif dan ancaman tersebut dipersepsikan mengganggu konsep diri atau integritas diri sehingga timbul harga diri rendah (Stuart \& Laraia, 2012). Dalam situasi yang tertekan, seseorang dengan beban psikologis yang kronis tanpa disertai dukungan dari keluarga dan orang sekitarnya, klien berusaha membebaskan beban pikiran dan perasaannya dengan reaksi kesal, marah serta menunjukkan perilaku kekerasan tanpa kendali (Bademli \& Duman, 2014).

Skizofrenia erat hubungannya dengan kejadian bunuh diri, dan lebih dari $90 \%$ dari satu juta kasus bunuh diri setiap tahunnya merupakan gangguan jiwa (WHO, 2009). Dampak kerugian lainya adalah bertambahnya beban untuk menanggung biaya berobat dikarenakan klien tidak bisa produktif lagi dalam bekerja dikarenakan disabilitas gangguan jiwa. Pada tahap awal disabillitas mental, keluarga akan mencari pertolongan secara simultan dengan budget pengeluaran yang tidak sedikit (Prakosa, 2005). Pasien dengan gangguan jiwa berjumlah lebih dari $80 \%$ mengalami kekambuhan dan menunjukkan episode berulang secara progresif pada fungsi-fungsi pasien meliputi fungsi kognitif, sosial, pekerjaan dan psikososial (Gold, et al., 2015). Prevalensi tersebut akan semakin meningkat apabila tidak dilakukan upaya pencegahan terhadap skizofrenia serta upaya pengobatan dan perawatan klien dengan baik dan sesuai.

Terapi kelompok berbasis CognitiveBehavior Therapy (CBT) menjadi sangat efektif untuk mengatasi gangguan ekspresi marah dan perilaku kekerasan karena dalam terapi ini anggota kelompok mempelajari strategi dan teknik untuk membantu mengendalikan kemarahan, mengekspresikan marah dengan cara sehat, mengubah sikap permusuhan, dan mencegah perilaku agresi dan kekerasan (Talakar, 2016). Penelitian yang dilakukan Sasmita (2007) diperoleh kemampuan kognitif harga diri rendah klien skizofrenia meningkat secara bermakna setelah diberikan CBT sebesar 17,14 dengan $p$-value $\leq \mathrm{a} \quad 0,05$ dibandingkan kelompok kontrol 7,72. Demikian pula penelitian Fauziah (2009) telah membuktikan bahwa Cognitive Behavior Therapy (CBT) dapat meningkatkan kemampuan kognitif klien perilaku kekerasan sebesar 7,92 dengan $p$ value $\leq \mathrm{a}$ 0,05 dibandingkan kelompok kontrol. Sedangkan Maryatun (2018) dalam penelitiannya diperoleh nilai rerata dari masing-masing responden mengalami penurunan skor harga diri rendah dari 20,22 menjadi 13,1 setelah klien diberikan Cognitive Behaviour Therapy (CBT) dengan waktu pelaksanaan 5 sesi selama 2-3 minggu.

Meskipun Cognitive Behaviour Therapy (CBT) pada penelitian sebelumnya telah berhasil mengatasi masalah harga diri rendah pada klien skizofrenia namun dalam pelaksanaannya, masih ditemukan hambatan antara lain lamanya sesi pelaksanaan CBT, kebosanan pada peserta, prosedur CBT yang sistematis dengan ketergantungan pada terapis serta dokumentasi tugas tertulis yang harus dikerjakan peserta menyebabkan klien terbebani dan cendrung kembali pada perilaku maladaptif seperti mengurung diri sendiri, lebih banyak diam, muncul masalah lanjutan seperti halusinasi, dan perilaku kekerasan (Hastuti, 2015). Permasalahan tersebut yang akhirnya dicari jalan keluarnya oleh peneliti dengan penggunaan media flashcard yang kreatif, interaktif, inovatif dan sederhana dalam penerapan Cognitive Behaviour Therapy (CBT). Melalui fashcard ini, pasien dimudahkan 
untuk tidak lama berpikir menemukan atau mengidentifikasi pikiran negatif yang sering terjadi pada penelitian CBT sebelumnya dikarenakan didalam setiap kartu flashcard sudah tertulis 1 pikiran negatif yang sering muncul secara otomatis dan dikeluhkan pasien disertai dengan gambar yang menunjukkan perasaan yang sesuai dengan pernyataan pikiran yang ada dibalik kartu. Demikian pula dengan kartu pikiran positif yang sudah ada didalamnya untuk kemudian pasien dipilih menggantikan kartu pikiran negatif dengan jumlah kartu semuanya adalah 32. Terapi CBT dengan flashcard ini bisa dilakukan dengan 2-6 orang pasien dengan 5 sesi dapat dilakukan 1-2 hari lebih singkat dibandingkan penelitian CBT sebelumnya. Penelitian ini mengadopsi metode permainan kartu remi dengan menggunakan flashcard CBT, mengutamakan reinforcement (penghargaan) pernyataan positif kepada setiap pasien dan bukan berdasarkan pemenang permainan.Dengan demikian pasien merasa senang dan nyaman, meningkat harga dirinya dan mampu mengingat pikiran positif yang baru dalam kartu flashcard serta mengaplikasikan dalam bentuk perilaku yang positif. Tujuan penelitian ini adalah pertama untuk mengetahui karateristik responden yang ikut serta dalam pemberian Cognitive behavioral Therapy (CBT), yang kedua untuk mengidentifikasi tingkat harga diri pasien skizofrenia sebelum dan sesudah pada kelompok kontrol dan kelompok intervensi yang diberikan Cognitive Behavioral Therapy (CBT) dengan Flashcard. Selanjutnya tujuan penelitian ketiga untuk mengetahui perbedaan (penurunan prosentase) tingkat harga diri pasien skizofrenia antara 2 kelompok kontrol dan intervensi yag diberikan Cognitive Behavioral Therapy (CBT) dengan Flashcard, serta yang keempat penelitian ini juga bertujuan untuk mengetahui efektifitas penggunaan Flashcard dalam penerapan Cognitive Behaviour therapy (CBT) pada pasien skizofrenia dengan harga diri rendah

\section{METODE}

Penelitian ini menggunakan desain "Quasi Experimental Pre-Post Test with Control group" dengan intervensi Cognitive Behaviour Therapy (CBT) dengan media flashcard. Penelitian dilakukan untuk mengetahui penurunan gejala dan kemampuan CBT pada klien dengan harga diri rendah sebelum dan sesudah diberikan perlakuan berupa pemberian terapi $C B T$ dengan menggunakan flashcard. Sampel dalam penelitian ini berjumlah 50 orang dengan 25 orang termasuk dalam kelompok intervensi dan 25 orang termasuk dalam kelompok kontrol. Tehnik pengambilan sampel dalam penelitian ini adalah purposive sampling (Arikunto, 2014). Pengambilan sampel didasarkan pada kriteria inklusi yaitu klien usia 18-55 tahun, diagnosa medis skizofrenia, masalah keperawatan harga diri rendah, tidak sedang amuk, mampu kooperatif selama mendapatkan psikofarmaka, telah dirawat di RS minimal 1 minggu dan bersedia menjadi responden. Pada kelompok kontrol, pasien tidak diberikan terapi CBT. Sedangkan pada kelompok kontrol diberikan terapi CBT dengan flashcard. Sebelum penelitian dilakukan pre-test pada kedua kelompok dengan menggunakan kuesioner Rosenberg untuk harga diri rendah. Setelah itu pada kelompok intervensi dibagi 5 kelompok kecil dengan masing kelompok terdiri dari 5 orang pasien dengan jadwal CBT yang berbeda. Lamanya CBT diberikan 1-2 jam sebanyak 5 sesi langsung yaitu pertama mengindentikasi pikiran otomatis dengan mengambil kartu sebanyak 4 lembar yang berisikan pikiran negatif, mengungkapkan pikiran otomotis negatif dari kartu nya yang sama dengan pikiran negatif teman lainnya serta mendiskusikan alasan pasien mempunyai pikiran negatif sesuai yang ada di kartu, sesi 2 mendiskusikan perasaan pasien mempunyai pikiran negatif dan keinginan untuk mengganti dengan pikiran positif, sesi 3 memilih kartu pikiran positif yang warna nya sesuai dengan warna kartu pikiran negatif. Satu jenis kartu pikiran negatif mempunyai 4 kartu pikiran positif. Sesi 4 mendiskusikan perilaku positif yang sesuai dengan pikiran positif yang tertera didalam kartu. Sesi 5 melatih dan mempraktekkan perilaku positif yang dipilih sebelumnya. CBT ini dilakukan sebanyak 3 kali dalam seminggu. Setelah itu pada kedua kelompok dilakukan post-test.

Data penelitian ini dianalisis secara univariat dan bivariat. Analisis univariat untuk menganalisis distribusi frekuensi karateristik data numerik yaitu umur dan respon tanda gejala kemampuan seperti respon kognitif, afektif, perilaku, fisiologis dan sosial dengan menggunakan sentral tendensi. Sedangkan analisis data kategorik meliputi jenis kelamin, pendidikan, riwayat gangguan jiwa dan pengalaman dirawat sebelumnya menggunakan uji Independent sampel T-test. Sedangkan uji analisa bivariat untuk mengetahui perubahan tanda gejala respon harga diri rendah meliputi respon kognitif, afektif, fisiologis, perilaku, 
dan sosial sebelum dan sesudah mendapatkan CBT dengan flashcard pada masing-masing kelompok dengan menggunakan $t$ Dependent. Uji $t$ Independent digunakan untuk mengalisis perubahan tanda gejala respon harga diri rendah meliputi respon kognitif, afektif, fisiologis, perilaku dan sosial setelah pemberian $C B T$ dengan flashcard pada kedua kelompok intervensi dan kontrol.

HASIL

Tabel 1. Analisis Kesetaraan Usia Klien pada Kelompok Intervensi dan Kontrol

\begin{tabular}{lcccrrrr}
\hline Variabel & Kelompok & n & Mean & Median & SD & Min-max & p-value \\
\hline \multirow{3}{*}{ Usia } & Intervensi & 25 & 30,43 & 29,0 & 8,137 & $18-50$ & \\
\cline { 2 - 7 } & Kontrol & 25 & 30,09 & 30,0 & 7,182 & $18-47$ & \multirow{2}{*}{0,565} \\
\cline { 2 - 7 } & Total & 50 & 30,26 & 29,5 & 7,659 & $18-50$ & \\
\hline
\end{tabular}

Berdasarkan tabel 1 menunjukkan ratarata usia pada kedua kelompok homogen dengan tidak ada perbedaan yang bermakna rata-rata usia klien pada kelompok yang mendapatkan $C B T$ dengan flashcard dengan kelompok yang tidak mendapatkan $C B T$ dengan $p$-value $0,565 \geq \mathrm{a} 0,05$.

Tabel 2. Analisis Kesetaraan Karateristik Klien pada Kelompok Intervensi dan Kelompok Kontrol

\begin{tabular}{|c|c|c|c|c|c|c|c|}
\hline \multirow{2}{*}{ Karateristik } & \multicolumn{2}{|c|}{ Kelompok intervensi } & \multicolumn{2}{|c|}{ Kelompok kontrol } & \multicolumn{2}{|c|}{ Jumlah } & \multirow{2}{*}{ p-value } \\
\hline & $\mathbf{n}$ & $\%$ & $\mathbf{n}$ & $\%$ & $\mathbf{n}$ & $\%$ & \\
\hline \multicolumn{8}{|l|}{ Jenis Kelamin } \\
\hline Laki & 16 & 64,0 & 20 & 80,0 & 36 & 72,0 & 0,487 \\
\hline Wanita & 9 & 36,0 & 5 & 20,0 & 14 & 28,0 & \\
\hline \multicolumn{8}{|l|}{ Pekerjaan } \\
\hline Pelajar & 1 & 4,0 & 2 & 8,0 & 3 & 6,0 & 0,502 \\
\hline PNS & 1 & 4,0 & 0 & 0 & 1 & 2,0 & \\
\hline Wiraswasta & 12 & 48,0 & 10 & 40,0 & 22 & 44,0 & \\
\hline Tidak bekerja & 11 & 44,0 & 13 & 52,0 & 24 & 48,0 & \\
\hline \multicolumn{8}{|l|}{ Status Perkawinan } \\
\hline Kawin & 9 & 36,0 & 8 & 32,0 & 17 & 34,0 & 0,588 \\
\hline Cerai & 5 & 20,0 & 3 & 12,0 & 8 & 16,0 & \\
\hline Tidak kawin & 11 & 44,0 & 14 & 56,0 & 25 & 50,0 & \\
\hline \multicolumn{8}{|l|}{ Pendidik } \\
\hline SD & 8 & 32,0 & 9 & 36,0 & 17 & 34,0 & 0,521 \\
\hline SMP & 3 & 12,0 & 6 & 24,0 & 9 & 18,0 & \\
\hline SMA & 13 & 52,0 & 9 & 36,0 & 22 & 44,0 & \\
\hline PT & 1 & 4,0 & 1 & 4,0 & 2 & 4,0 & \\
\hline \multicolumn{8}{|c|}{ Riwayat Gangguan Jiwa } \\
\hline Ada & 9 & 36,0 & 12 & 48,0 & 21 & 42,0 & 0,277 \\
\hline Tidak ada & 16 & 64,0 & 13 & 52,0 & 29 & 58,0 & \\
\hline \multicolumn{8}{|l|}{ Frekuensi Dirawat } \\
\hline Pertama & 9 & 36,0 & 12 & 48,0 & 21 & 42,0 & 0,401 \\
\hline 2kali/lebih & 16 & 64,0 & 13 & 52,0 & 29 & 58,0 & \\
\hline
\end{tabular}

Berdasarkan tabel 2 dapat diketahui bahwa karateristik klien dalam penelitian ini lebih banyak berjenis kelamin laki-laki 36 orang (72\%), sebagian besar tidak bekerja 24 orang $48 \%$ ), status tidak menikah 25 orang (50\%), memiliki latar belakang pendidikan SMA 22 orang (44\%), dengan adanya riwayat gangguan jiwa 21 orang (42\%) dan frekuensi dirawat dirumah sakit $2 \mathrm{kali} / \mathrm{lebih} 29$ orang(58\%). Hasil analisis uji statistik kesetaraan karateristik berdasarkan jenis kelamin, pekerjaan, pendidikan, status pernikahan, riwayat gangguan jiwa dan frekuensi dirawat. Maka diperoleh tidak adanya perbedaan yang bermakna antara kelompok yang mendapatkan $C B T$ dengan flashcard dengan yang tidak mendapatkan $C B T$. Hal ini berarti kedua kelompok memiliki varian yang homogen. 
Tabel 3. Analisis Tanda dan Gejala Harga Diri Rendah pada Kelompok Intervensi dan Kelompok Kontrol

\begin{tabular}{llrrrr}
\hline $\begin{array}{c}\text { Tanda } \\
\text { gejala } \\
\text { HDR }\end{array}$ & Kel & n & Mean & SD & $\begin{array}{c}\text { Min- } \\
\text { max }\end{array}$ \\
\hline \multirow{2}{*}{ Kognitif } & Intervensi & 25 & 15,63 & 4,213 & $6-24$ \\
& Kontrol & 25 & 16,50 & 3,166 & $11-24$ \\
\hline \multirow{2}{*}{ Emosi } & Intervensi & 25 & 13,30 & 3,127 & $7-23$ \\
& Kontrol & 25 & 13,54 & 3,335 & $6-20$ \\
\hline \multirow{2}{*}{ Perilaku } & Intervensi & 25 & 17,30 & 4,213 & $10-26$ \\
& Kontrol & 25 & 18,50 & 3,889 & $10-29$ \\
\hline \multirow{2}{*}{ Sosial } & Intervensi & 25 & 13,02 & 3,456 & $10-19$ \\
& Kontrol & 25 & 13,67 & 4,225 & $11-18$ \\
\hline \multirow{2}{*}{ Fisiologis } & Intervensi & 25 & 6,87 & 1,375 & $5-11$ \\
& Kontrol & 25 & 7,56 & 1,187 & $5-10$ \\
\hline Komposit & Intervensi & 25 & 60,87 & 11,768 & $37-89$ \\
HDR & Kontrol & 25 & 63,21 & 11,276 & $41-84$ \\
\hline
\end{tabular}

Berdasarkan tabel 3, bahwa analisis dari tanda gejala kognitif, emosi ,perilaku, sosial dan fisiologis yang diakumulasikan dalam komposit tanda gejala harga diri rendah (HDR) adalah diperoleh dalam kategori rendah 27-54, sedang 54,1-90, tinggi 90,1-108. Hasil analisis tanda gejala klien pada tabel diatas memperlihatkan dari jumlah total 50 klien HDR menunjukkan rata-rata tanda gejala sebelum dilakukan $C B T$ dengan flashcard pada kedua kelompok adalah 61,79 dengan nilai minimal 37 dan nilai maksimal 89. Dengan demikian dari tabel 3 dapat dianalisi bahwa dari keseluruhan lima respon HDR menunjukkan bahwa rata-rata komposit tanda gejala klien HDR sebelum dilakukan terapi CBT dengan flashcard adalah sedang.

Tabel 4. Analisis Kesetaraan Tanda dan Gejala Harga Diri Rendah pada Kelompok Intervensi dan Kelompok Kontrol

\begin{tabular}{llcrrrr}
\hline Tanda gejala HDR & Kelompok & n & Mean & SD & Min-max & p-value \\
\hline \multirow{2}{*}{ Kognitif } & Intervensi & 25 & 15,63 & 4,213 & $6-24$ & 0,498 \\
& Kontrol & 25 & 16,50 & 3,166 & $11-24$ & \\
\hline \multirow{2}{*}{ Emosi } & Intervensi & 25 & 14,30 & 3,127 & $7-23$ & 0,788 \\
& Kontrol & 25 & 14,54 & 3,335 & $6-20$ & \\
\hline \multirow{2}{*}{ Perilaku } & Intervensi & 25 & 17,30 & 4,213 & $10-26$ & 0,328 \\
& Kontrol & 25 & 18,50 & 3,889 & $10-29$ & \\
\multirow{2}{*}{ Sosial } & Intervensi & 25 & 13,02 & 3,456 & $10-19$ & 0,496 \\
& Kontrol & 25 & 13,67 & 4,225 & $11-18$ & \\
\hline \multirow{2}{*}{ Fisiologis } & Intervensi & 25 & 6,87 & 1,375 & $5-10$ & 0,035 \\
\multirow{2}{*}{ Komposit HDR } & Kontrol & 25 & 7,56 & 1,187 & $5-10$ & \\
& Intervensi & 25 & 60,87 & 11,768 & $37-89$ & 0,395 \\
& Kontrol & 25 & 63,21 & 11,276 & $41-84$ & \\
\hline
\end{tabular}

Berdasarkan tabel 4, menunjukkan bahwa rata-rata nilai gejala harga diri baik pada kelompok yang mendapatkan $C B T$ dengan flashcard dan yang tidak mendapatkan $C B T$ berada pada tingkat yang sedang. Bila nilai ratarata tersebut dibandingkan pada kedua kelompok yang mendapatkan $C B T$ dengan flashcard dan yang tidak mendapatkan CBT menunjukkan angka yang tidak jauh berbeda. Hasil uji statistik tanda dan gejala harga diri rendah pada kelompok intervensi dibandingkan dengan kelompok kontrol sebelum kelompok intervensi mendapatkan terapi CBT dengan flashcard secara keseluruhan tidak ada perbedaan yang bermakna atau kedua kelompok dalam keadaan homogen (setara).

Tabel 5. Analisis Tanda dan Gejala Harga Diri Rendah Sebelum dan Sesudah di lakukan $C B T$ dengan Flashcard pada Kelompok Intervensi dan Kontrol

\begin{tabular}{llrrrrr}
\hline \multirow{2}{*}{ Tanda gejala HDR } & Kelompok & $\begin{array}{c}\text { Mean } \\
\text { Sebelum }\end{array}$ & $\begin{array}{c}\text { Mean } \\
\text { Sesudah }\end{array}$ & $\begin{array}{c}\text { Mean } \\
\text { Selisih }\end{array}$ & $\begin{array}{c}\text { SD } \\
\text { Selisih }\end{array}$ & p-value \\
\hline \multirow{2}{*}{ Kognitif } & Intervensi & 15,63 & 7,97 & 7,66 & 4,233 & 0,000 \\
& Kontrol & 16,50 & 13,76 & 2,74 & 3,755 & 0,000 \\
\hline \multirow{2}{*}{ Emosi } & Intervensi & 13,30 & 6,83 & 6,47 & 3,112 & 0,000 \\
& Kontrol & 13,54 & 11,92 & 1,62 & 3,986 & 0,000 \\
\hline \multirow{2}{*}{ Perilaku } & Intervensi & 17,30 & 8,96 & 8,34 & 3,245 & 0,000 \\
& Kontrol & 18,50 & 15,76 & 2,74 & 3,155 & 0,000 \\
\hline \multirow{2}{*}{ Sosial } & Intervensi & 13,02 & 7,03 & 5,99 & 3,178 & 0,000 \\
& Kontrol & 13,67 & 11,21 & 2,46 & 2,988 & 0,000 \\
\hline \multirow{2}{*}{ Fisiologis } & Intervensi & 6,87 & 5,23 & 1,64 & 1,221 & 0,000 \\
& Kontrol & 7,56 & 5,98 & 1,58 & 1,377 & 0,000 \\
\hline \multirow{2}{*}{ Komposit HDR } & Intervensi & 60,87 & 29,76 & 28,11 & 11,345 & 0,000 \\
& Kontrol & 63,21 & 53,55 & 9,66 & 11,230 & 0,000 \\
\hline
\end{tabular}


Berdasarkan tabel 5, hasil analisis tanda dan gejala harga diri rendah sebelum dan setelah dilakukan $C B T$ dengan flashcard pada kelompok intervensi dan kontrol terdapat perubahan yang bermakna dimana kedua kelompok sama-sama menurun,namun tingkat penurunannya yang berbeda. Penurunan yang lebih besar didapatkan pada kelompok intervensi dimana sebelum diberikan $C B T$ kelompok intervensi memiliki rata-rata tanda gejala harga diri 60,87 kategori gejala sedang, setelah intervensi rata-rata tanda gejala harga diri rendah turun menjadi 32,76 kategori gejala rendah atau penurunan tanda gejala harga diri rendah pada kelompok intervensi lebih dari 50\%. Sedangkan pada kelompok kontrol yang tidak mendapatkan perlakuan $C B T$, rata-rata tanda gejala harga diri sebelum dan sesudahnya masih dalam keadaan kategori sedang dengan nilai harga diri sebelumnya 63,21 dan sesudahnya menurun menjadi 53,55 dan penurunan tanda gejala harga diri rendah pada kelompok kontrol hanya $15 \%$

\section{Tabel 6. Analisis Penurunan Komposit Tanda Gejala Harga Diri Rendah Sebelum dan Sesudah Dilakukan CBT dengan Flashcard pada Kelompok Intervensi dan Kontrol

\begin{tabular}{llrrrrr}
\hline $\begin{array}{c}\text { Komposit } \\
\text { Tanda Gejala }\end{array}$ & Kelompok & $\begin{array}{c}\text { Mean } \\
\text { Sebelum }\end{array}$ & $\begin{array}{c}\text { Mean } \\
\text { Sesudah }\end{array}$ & $\begin{array}{c}\text { Mean } \\
\text { Selisih }\end{array}$ & $\begin{array}{c}\text { SD } \\
\text { Selisih }\end{array}$ & p-value \\
\hline Harga diri & Intervensi & 60,87 & 32,76 & 28,11 & 11,345 & 0,000 \\
rendah & Kontrol & 63,21 & 53,55 & 9,66 & 11,230 & 0,000 \\
\hline
\end{tabular}

Berdasarkan tabel 6, hasil analisis komposit tanda dan gejala harga diri sebelum dan setelah dilakukan $C B T$ dengan flashcard pada kelompok intervensi dan kontrol terdapat perubahan yang bermakna dimana kedua kelompok sama-sama menurun, namun penurunan yang lebih besar ditemukan pada kelompok intervensi. Respon komposit harga diri rendah klien menurun secara bermakna menjadi 32,76 (kategori rendah) pada kelompok intervensi dan kelompok kontrol komposit harga diri rendah klien menurun secara bermakna menjadi 53,55 (kategori sedang) dengan $p$-value $0,000 \leq \mathrm{a} 0,05$. Efektifitas terapi $C B T$ dalam menurukan tanda gejala harga diri rendah adalah $67,6 \%$.

\section{PEMBAHASAN}

\section{Analisis Tanda dan Gejala Harga Diri Rendah}

Berdasarkan tabel 3 dan 4, diperoleh bahwa kedua kelompok berada dalam kesetaraan yang homogen dimana tanda gejala harga diri rendah berada dalam kategori sedang. Harga diri rendah adalah evaluasi diri, perasaan dan kemampuan diri yang negatif secara langsung dan tidak langsung diekspresikan (Stuart \& Laraia, 2012). Perubahan harga diri dapat terjadi ketika individu mengalami intervensi kognitif yang disusun untuk merestrukrisasi proses evaluasi dirinya (Granholm, et al., 2005). Harga diri rendah dapat menyebabkan berbagai dampak negatif pada kondisi psikologis individu.

Harga diri rendah dapat menjadi faktor etiologi pada gangguan mental seperti waham dan perilaku kekerasan (Jumaini, et al., 2011). Hal tersebut menunjukkan pasien dengan harga diri rendah mengalami pikiran negatif dan kesalahan dalam menilai dirinya sendiri secara negatif, sehingga dengan diberikan $C B T$ dengan media flashcard maka pasien akan mengubah pernyataan negatif dan mengubah keyakinan irrasional serta caraberpikir tidak logis dalam evaluasi dirinya. Oleh karena itu strategi kognitif behavioural menjadi intervensi asuhan keperawatan yang tepat untuk meningkatkan harga diri (Froggatt, 2005).

\section{Analisis Tanda dan Gejala Harga Diri Rendah Sebelum dan Sesudah dilakukan $C B T$ dengan Flashcard}

Berdasarkan tabel 5 diperoleh bahwa terjadi penurunan tanda gejala harga diri rendah yang lebih besar pada kelompok intervensi dibandingkan kelompok kontrol dimana respon gejala harga diri rendah turun menjadi 32,76 kategori gejala rendah sedangkan pada kelompok kontrol, rata-rata tanda gejala harga diri rendah sesudahnya masih dalam keadaan kategori sedang, dengan penurunan hanya $15 \%$. Penelitian serupa dilakukan Sasmita (2007) menunjukkan $C B T$ berpengaruh terhadap respon kognitif dan perilaku klien dengan masalah harga diri rendah sebesar 32,41\%. Terapi generalis pada kelompok kontrol menyebabkan penurunan tanda dan gejala harga dri rendah sebesar 7,17. Penelitian lainya yang sejalan dilakukan Hidayat ( 2011) dimana CBT mampu menurunkan tanda gejala harga diri sebesar 37,83\%. Stuart (2012) menyatakan bahwa $C B T$ bertujuan untuk mengubah keyakinan tidak rasional, kesalahan penalaran dan pernyataan negatif tentang keberasaan individu (Stuart \& Laraia, 2012) 
Cogntive behavior therapy (CBT) adalah terapi yang membantu individu merubah cara berfikir dan perilakunya sehingga perubahan itu membuat individu merasa lebih baik dan terapi ini berfokus pada penyelesaian masalah here and now (Dopke \& Batscha, 2014). Hasil penelitian ini sesuai dengan pendapat Riechet (2009) menyatakan terapi $C B T$ secara signifikan dapat mengurangi kemarahan, perasaan bersalah dan harga diri. Banyak pasien harga diri rendah mengalami, kesulitan dalam mengidentifikasi perasaannya, kebutuhannya dan keinginannya untuk diungkapkan pada orang lain.Sedangkan menurut Cristopher menyatakan bahwa ada hubungan antara pemikiran dan emosi yang berperan penting dalam performance perilaku (Corrigan, 2012).

Flashcard merupakan media interaktif yang membantu pasien untuk mengidentifikasi pikiran, mengungkapkan perasaan serta menjadi reinforcement dalam aplikasi perilaku yang positif. Gambar yang ada di flashcard memiliki keterangan, gambar dan pesan yang dapat mengeluarkan ide-ide munculnya pikiran positif (Nurwidayati, 2015). Berdasarkan hasil penelitian, salah satu responden Tn M mendapat kartu negatif dengan isi bahwa klien jelek dimana pikiran negatif tersebut juga sering muncul dipikirkan 3 responden lainnya,respon perasaan yang diungkapkan adalah sebagian merasa sedih. Setelah diberikan terapi flashcard, responden mampu mengidentifikasi kartu yang berisikan pikiran positif yaitu saya biasa-biasa saja, tapi saya cantik dengan perilaku bersih dan rapi dengan melakukan kegiatan membersihkan ruangan tempat tidur dan menjaga kebersihan diri setiap harinya.Setelah diberikan terapi, tanda gejala harga diri rendah responden berkurang dibandingkan sebelum diberikan terapi dengan flashcard menjadi dalam kategori rendah (menurun). Menurut hasil evaluasi subjektif, responden mengatakan permainan $C B T$ dengan flashcard ini sangat mudah, menarik dan mudah diingat kata-kata positifnya. Pernyataan responden tersebut sesuai dengan pendapat Susilana dan Riyana (2009) yakni flashcard mempunyai keuntungan antara lain mudah dibawa kemana-mana, praktis dalam penggunaannya tidak perlu memiliki keahlian khusus sebab mudah diingat dan menyenangkan. Penelitian telah menunjukkan $C B T$ efektif dalam mengurangi gejala dan kekambuhan pasien dengan atau tanpa pengobatan dalam masalah klinis terutama depresi, ansietas, gangguan makan, gangguan kepribadian dan skizofrenia. Terapi generalis yang didapatkan kelompok kontrol juga memberikan dampak penurunan tanda gejala namun secara statistik kemaknaannya masih lebih rendah, hal ini disebabkan pasien yang dirawat dirumah sakit tetap mendapatkan dan mengikuti standar diagnose keperawatan jiwa yang menjadi dasar untuk berperilaku dan melaksanakan fungsi sosial dan problem solving.

\section{Analisis Perubahan Penurunan Tanda Gejala Harga Diri Rendah Setelah Dilakukan CBT dengan Flashcard}

Berdasarkan tabel 6, hasil penelitian menunjukkan adanya perubahan yang bermakna pada tanda gejala harga diri rendah setelah mendapatkan terapi cognitive behavior therapy (CBT)dengan flashcard dibandingkan pasien yang tidak mendapatkan terapi cognitive behavior therapy dengan nilai $p$-value 0,000 ( $p$ value $\leq 0,05)$. Hal ini disebabkan karena $C B T$ merupakan salah satu psikoterapi yang dapat meningkatkan kemampuan kognitif dan perilaku pasien skizofrenia dengan harga diri rendah dan resiko perilaku kekerasan dalam mengatasi masalahnya. Hasil penelitian juga menunjukkan rata-rata penurunan respon harga diri rendah (kogntif, emosi, perilaku, fisiologis dan sosial) pada kelompok intervensi lebih besar dibandingkan kelompok kontrol. Hal ini merupakan faktor dari adanya perlakuan terapi cognitive behavior therapy (CBT) yang tindakannya lebih kepada inti permasalahan dari pasien yakni keyakinannya terhadap situasi, lingkungan, orang lain dan lingkungan yang diinterpretasikan secara salah melalui proses kognitif dan pada akhirnya dimanifestasikan dalm bentuk perilaku (output).

Berdasarkan tabel 6 tersebut, terjadi penurunan yang dan perubahan signifikan pada respon tanda gejala harga diri rendah pada kelompok intervensi yaitu $57 \%$. Hasil penelitian ini sejalan dengan penelitian Lelono (2011) dimana efektifitas $C B T$ sebesar $62,2 \%$ mampu menurunkan gejala harga diri rendah. Berdasarkan penelitian ini, bahwa pada pasien skizofrenia ternyata respon kognitif dan perilakunya juga dapat diubah menjadi positif apabila diberikan terapi cognitive behavior therapy (CBT) walaupun dalam prosesnya, pasien tetap mendapatkan terapi antipsikotik, namun pasien dapat berpikir secara rasional dan dapat dilatih untuk memecahkan masalah melalui bantuan dari flashcard yang berisikan pikiranpikiran positif. Hasil penelitian ini sejalan dengan penelitian Turkington dan Kingdon (2006) yang menunjukkan hasil yang cukup memuaskan dimana tehnik yang digunakan berorientasi pada 
masalah dan tugas dalam mengubah kognitif yang salah atau bias dengan menilai situasi dan memodifikasi perilaku baru yang adaptif.

Pada penelitian ini responden dibantu untuk berorientasi pada flashcard awal yang berisikan pikiran negatif yang sering muncul dan menggangu pikirannya, kemudian responden menceritakan pengalaman pikirannya tersebut, selanjutnya responden mengambil flashcard lain yang berisikan 4 macam pikiran positif yang cocok dipasangkan dengan flashcard pertama. Responden yang paling banyak menemukan dan memasangkan kartu-kartu tersebut dan melaksanakan perilaku yang sesuai dengan pikiran positifnya maka mendapatkan reinforcement. Terapi bermain $C B T$ dengan flashcard secara berkelompok yang dijadwalkan tiga kali seminggu terbukti efektifitasnya dalam menurunkan respon tanda dan gejala harga diri rendah.

\section{SIMPULAN}

Karakteristik responden pada penelitian ini sebagian besar rata-rata responden berusia 30,46 tahun dengan jenis kelamin paling banyak adalah laki-laki $70 \%$, tidak bekerja $48 \%$, status tidak kawin 50\%, memiliki jenjang pendidikan SMA $44 \%$, tidak adanya riwayat gangguan jiwa $58 \%$ dan frekuensi dirawat di rumah sakit lebih dari 2 kali sebanyak 58\%. Tingkatan harga diri rendah pada kelompok intervensi sebelum dan sesudah diberikan Cognitive Behavioral Therapy (CBT) dengan flashcard mengalami penurunan lebih dari 50\% dengan kategori rendah. Sedangkan pada kelompok kontrol terdapat penurunan sebesar $15 \%$ tanda gejala harga diri rendah responden dengan kategori sedang.

Kedua kelompok sama-sama mengalami perubahan yang bermakna dengan penurunan tanda dan gejala harga diri rendah namun penurunan lebih besar diperoleh pada kelompok intervensi yang diberikan Cognitive Behavioral Therapy (CBT) dibandingkan kelompok kontrol. Adapun efektifitas Cognitive Behavioral Therapy (CBT) dengan flashcard dalam menurunkan tanda gejala harga diri rendah adalah sebesar $67,6 \%$.

Journal of Rational Emotive Behavioural Therapy, 16(2): 167-176.

Granholm E, et al. (2005). Group Cognitive Behavioural Social Skill Training For Older Outpatients with Chronic Schizophrenia. Journal of Cognitive Psychoterapy: International Quarterily, 18(3):265-279.

Gold K, Duffy M, Hackmann D. (2015). Community Based Cognitive Therapy in Treatment of Post-Traumatic Stress Disorder. Journal of Behavior Research Therapy, 40(1): 345-357.

Hastuti, R. Y., Keliat, B. A., \& Mustikasari, M. (2015). Efektivitas Rational Emotive Behaviour Therapy Berdasarkan Profile Multimodal Therapy pada Klien Skizofrenia dengan Masalah Keperawatan Perilaku Kekerasan dan Halusinasi di Rumah Sakit Jiwa. Jurnal Keperawatan Indonesia, 18(3), 143-148.

Hidayat, A. (2011). Pengaruh Cogntive Behavioural Therapy dan Rational Emotive Behavioral Therapy pada Perilaku Kekerasan dan Harga Diri Rendah. [Tesis].

Froggatt, W. (2005). A brief Introduction to Rational Emotive Behaviour Therapy. 
Depok: Fakultas Ilmu Keperawatan, Universitas Indonesia.

Jumaini, Hamid AY, Wardani IY. (2011). Penerapan Terapi Kognitif Pada Klien Harga Diri Rendah Kronis Dengan Teori King. Laporan Akhir Praktek Lapangan. Tidak dipublikasikan.

Laporan PKL. (2017). Data Rekam Medis RS Ernaldi Bahar Sumatra Selatan Tahun 2017. Tidak dipublikasikan.

Lelono, SK. (2011). Efektivitas Cognitive Behaviour Therapy dan Rational Emotive Behaviour Therapy Terhadap Klien Perilaku kekerasan, Halusinasi dan Harga Diri Rendah. [Tesis]. Depok: Fakultas Ilmu Keperawatan, Universitas Indonesia.

Maryatun, S. (2018). Pengaruh Cognitive Behaviour Therapy terhadap Perubahan Harga Diri Pasien Perilaku Kekerasan dengan Aplikasi Token Economy. Proceeding Seminar Nasional Keperawatan. Universitas Sriwijaya, 4(1):193-198.

Nurwidayati, A. (2015). Peningkatan Perkembangan Kognitif Anak Usia Dini melalui Permainan Flashcard di Pos PAUD. Jember.

Prakosa, P. W. (2005). Dimensi Sosial Disabilitas Mental di Komunitas Semin, Yogyakarta. Sebuah Pendekatan Representasi Sosial. Jurnal Psikologi, 32(2), 61-73.

Riechet. (2009). CBT for post traumatic stress disorder. The Journal of Social Psychology. New York: The Guilford
Press, Vol. 141(1): 119-121.

Sasmita, H, B.A. Keliat. (2007). Efektifitas Conitive Behaviour Therapy Pada Klien Harga Diri Rendah di RS Marzoeki Mahdi Bogor. [Tesis]. Depok: Fakultas Ilmu Keperawatan, Universitas Indonesia.

Stuart \& Laraia. (2012). Mental Health Nursing. New York: The Guildford Press.

Stolzer, J. (2016). The Meteoric Rise of Mental Illness in America and Implications for Other Countries. The European Journal of Counseling Psychology, 4(2):231-246.

Susilana, R, Riyana C. (2009). Media Pembelajaran: Hakikat, Pengembangan, Pemanfaatan dan Penilaian. Bandung: CV Wacana Prima.

Syamsulhadi. (2018). Profil Riskesdas 2013 \& 2018. Terapi Psikososial Pasien Skizofrenia. Bali. National Conference on Schizophrenia.

Talakar, M, Haghayegh SA, Mirzain B. (2016). The Effect of Cognitive Behavioural Therapy on Anger. Iran $J$ Psychiatriy Behav Sci, 10(4): e1250.

Turkington, D., Kingdon, D., \& Weiden, P. J. (2006). Cognitive behavior therapy for schizophrenia. American Journal of Psychiatry, 163(3), 365-373.

World Health Organization. (2011). The World Medicine Situation. Rational Use of Medicine GENEVA.

World Health Organization. (2009). World Health Statistics. Geneva. 